\title{
Research on the Strategy of Promoting Gender Mainstreaming Effectively
}

\author{
Zhen-huan ZHANG ${ }^{1, a,{ }^{*}}$ \\ ${ }^{1}$ Beijing WuZi University, Ideological and Political Department, China Beijing 101149 \\ azhenhuan2000@163.com \\ ${ }^{*}$ Corresponding author
}

Keywords: Gender, Mainstreaming, Woman.

\begin{abstract}
It is a solemn promise of Chinese government to promote gender mainstreaming. But in China the strategy of gender mainstreaming is far from realization under the influence of traditional social gender culture. At the national level, the measures of promoting gender mainstreaming can be summarized as follows: Enhancing the sensitivity and recognition of decision makers on gender issues; Introducing advanced gender analysis tools to develop policies; Implementing gender equality budget to ensure that the mainstream of social gender is transformed from the concept of level into a practical action; Increasing the strength of women's empowerment; Establishing social support system; Establishing women's special contribution compensation system to ease the role of women in conflict, promoting women to become the master in development and get rid of the subordinate status; Improving the implementation of the women's policy.
\end{abstract}

Gender mainstreaming, the introduction of gender awareness into social development and decision-making mainstream, first appeared in the 1985 Third World Women's Congress. In 1995 UN Fourth World Conference on Women formally proposed gender equality into the mainstream, and wrote it to the Beijing Platform for Action. In 1997, the United Nations Economic and Social Council adopted the definition of gender mainstreaming: The process of assessing the implications for women and men of any planned action, including legislation, policies or programs, in all areas and at all levels. It is a strategy for making women's as well as men's concerns and experiences an integral dimension of the design, implementation, monitoring and evaluation of policies and programs in all political, economic and societal spheres so that women and men benefit equally and inequality is not perpetuated. The ultimate goal is to achieve gender equality.

China is one of the 49 countries committed to gender mainstreaming after World Women's Congress and make a substantial effort in advancing gender mainstream. But China, after all, is a country with thousands of years of feudal history, and is in and will be in the primary stage of socialism. Influenced by the traditional gender culture, the gender consciousness is not sensitive or missing in the formulation of public policy and laws and regulations in China, such as the right to survival of female fetus, female college students' employment problem and women's commercialization of sex and so on. China's efforts to promote gender equality cannot fully meet the needs of the reality and governments at all levels are still insufficient in

\footnotetext{
* Zhenhuan Zhang, female, born in 1976.10, Doctor, Post-doctoral in reading at Chinese Academy of Social Sciences, associate Professor, a teacher of Ideological and Political Department, Beijing Wuzi University, from Heilongjiang, researching Localization of Marxism in China, cell phone: 13691331516, Email: zhenhuan2000@163.com.
} 
achieving gender mainstream. Gender mainstreaming in China is still a strategy far from being realized. How to accelerate the process of gender mainstreaming in our country? On the basis of drawing lessons from the experience of the international community, the author believes that in the system, policy, laws and regulations, the main work of promoting gender mainstreaming is as follows:

\section{At the Level of Women's Development Policy Making}

\section{Strengthening the Training to Strengthen the Awareness and Sensitivity of the Decision-making to Gender Issues}

Decision maker is the representative of the authority of the government and the main body of the policy making. The gender consciousness of policy makers has a direct impact on the fairness of the gender policy. At present, it has achieved a better effect to promote the gender mainstreaming through educating and training the gender consciousness of decision-makers in foreign countries. Some similar attempts have been made in some areas of our country. But there is very little social gender training for policy decision makers and the training system is not institutionalized.

\section{Introducing Advanced Gender Analysis Tools to Strengthen the Gender Perspective and Develop Gender Sensitive Policies}

Before making any major policy, the advanced gender analysis tools and methods should be used to analyze the different results that maybe caused by the policy between male and female and then the positive gender sensitive policies to eliminate gender inequality will be built. When building a policy, making necessary social gender analysis can effectively avoid the lack of gender in the policy, reduce remedy afterwards and prevent new social contradictions to embody the principle of gender equality in the relevant laws, regulations, policies and development planning and improve the scientific decision-making.

\section{Implementing Gender Equality Budget, to Ensure that Gender Mainstreaming Changes from the Concept Level into A Real Action}

Social gender budget refers to analyzing the government's fiscal revenue and public expenditure from the perspective of gender checking its different influence between women and men. In the process of promoting gender mainstreaming, financial support is an important means of gender mainstreaming. Without budget support, achieving gender mainstreaming can only be a slogan that cannot be translated into real action. Learning from the successful international experience, China government departments should attach great importance to the work of social gender budget and bring the gender consciousness into the China department budget system and take it as one of the content at the annual meeting of People's Congress to consider the budget. At the same time, the construction of the mechanism of gender budget and capacity building should be strengthened to ensure that gender mainstreaming changes from the concept level into a real action.

\section{Increasing the Strength of Women's Empowerment}

Empowerment refers to the process that individuals or groups challenge the existing power relations and regain their proper power in social life and family. Women's empowerment refers to the process in which women recognize and gain equal rights with men in the family and social life. It includes two levels of meaning: women's reacquainting their due right in the family and society, accessing to rights based on 
accessing to equality consciousness. Women's empowerment is composed of five parts: the perception of self-worth; having the right to choose and decide; getting the opportunity to use the resource rights; a powerful right to control his life (home); the ability to influence domestic and international social change direction to create a more equitable social and economic order. I believe that at this stage the increasing of women's empowerment efforts should begin from the following aspects:

First empowerment requires women groups to be awakened to make every woman have equal consciousness and the ability to maintain their equal rights. Then the whole group of women can have power. Women should get the inner strength to be able to express their own interests, to organize, to issue a more effective political voice, to defend the rights of the group and to win more self-esteem.

Secondly, the government should step up efforts to train and select spokesmen for the interests of women. Female leading cadres in our country are lack of gender consciousness of speaking and working for women. As the representative of women's participation in politics, female leading cadres most probably protect women's rights in the decision-making body. But in reality most of the female leading cadres consider their success to be the result of personal effort and has nothing to do with women group. They regard politics as a personal matter and don't consider themselves as the representative of women's participation in politics. According to the relevant research of the United Nations, representatives of any group in the decision-making level have a real impact on public policy only they reach more than $30 \%$ of the proportion. The majority of women female leading cadres are deputy in internal power structure of our country and obviously this ratio is far from reaching. It is because of the absence of women in the decision-making layer that makes the situation of marginalization of women group's interests so serious. It can be said that the lack of spokesmen for the interests of women in the decision-making is the main obstacle to promote gender mainstreaming in our country at present. When Mrs. Thatcher became a British Prime Minister, many people took it for granted that she would be a spokeswoman for the rights of women. But in fact she never considered herself as a representative of the interests of women. During her ruling period, she did not do any preferential policies for women. Instead she tried to implement new liberal policies that were harmful to most women, and cut down on the welfare of women and children. It is a key problem for promoting gender mainstreaming to cultivate a large number of representatives of women's interests, put them into the decision-making, speak for women's voice, and impact the development of relevant policies.

Lastly, at the policy making, monitoring and evaluation level, the participation degree of women research specialist in decision making should be increased. Only professionals can grasp the advanced gender analysis tools. The government should use gender analysis tools and methods to master the realistic gender gap in policy making. When implementing the policy, traditional gender rule should be weakened as much as possible to avoid the negative effect on women. A policy that does not have gender implications is likely to produce a result of sex discrimination in practice.It will require us to use gender analysis tools and methods to analyze and evaluate the impact of the actual operation of the policy when assessing the effectiveness of the policy implementation. We should review the gender consciousness sensitivity of the policy from the effect of decision making and realize what we expect and what the result is so as to continuously improve the decision making and overcome the possible gender bias. It requires women research specialist to involve in make professional analysis on policy making, monitoring and evaluation etc. Therefore, it is significant to increase the degree of participation of women 
research specialist for improving the scientific and gender sensitivity of the policy. At present, China's construction in this area is still relatively backward. I propose to establish a committee of women research specialist. It specializes in gender impact analysis, provides advisory services, and has the authority to review existing and new policies for women's development and important laws, strategies, policies and plans made by various government departments and effectively promotes gender mainstreaming into macro decision making.

\section{Strengthening the Relevance and Synergy of Relevant Policies, and Establishing Social Support System}

The gender issue is not a simple problem to mediate the relationship between the sexes, but a power relationship. Changing the original unequal power system from structure requires changes in politics, economy, culture, society and so on. Gender policy doesn't always coincide with politics, economy, culture and social policy and there are conflicts between them. By giving women a longer parental leave and improving women's childcare subsidies to reducing the economic burden of women, conditions and environment for women to take care of their children will be greatly improved. But in the long run these measures will further strengthen the traditional gender division of labor and solidify females breed characters, and then possibly further strengthen the subordinate status of women. Therefore, when making policy the government should consider various factors, and stick to the human development and happiness of life oriented principles, and strengthen the relevance and synergy of relevant policies and establishing social support system so as to really make gender policy coincide with politics, economy, culture and social policy.

\section{Establishing Special Contribution Compensation System for Women to Ease the role of Women in Conflict, Promoting Women to Become the Master in Development and Get Rid of the Subordinate Status}

The traditional gender concept that "men played the key role in the society while women were confined to the family chores" takes man as the breadwinner and woman as the housewife. The evaluation criteria for men's contribution and achievement are often money, power, and professional reputation, while the evaluation criteria for women's contribution and achievement is that if she has become a "fine wife and mother". The social evaluation criteria for successful women are not their economic ability or professional ability, but their household role. If a "superwoman" is too busy to look after her family, she is often accused of "selfish" and "not family-oriented". On the one hand, the State encourages women to work hard in the workplace; on the other hand, the state requires women to bear family responsibility, to respect the old and cherish the young, to arrange the family affairs and coordinate the family relationship. The women who can balance work and family are called "super fine wife and mother". That is, they are not only strong person who have ideals, are ambitious and are competent but also "good wife", "good mother" and "good wife" who build modern "civilized family". But the roles of "market man" and "Family man" played by women are conflict and can't perfectly coordinate. "The market is a collection of private interests, is the place of commodity trading and is the battlefield of competition, while the family is a representative of the collective, is the cradle of nurturing life, and is a cooperative unit. The ultimate goal of the market is to maximize the interests of individuals, while the highest mission of the family is maximization of family interests and the harmonious relationship among family members. ...... Market requires everyone to go to all lengths in order to maximize the 
benefits of the individual, while family requires everyone to take into account the interests of the family and to take care of the family members. These two kinds of requirements are contradictory. Caring for family members requires people's time and effort which will reduce their market efficiency and even makes them eliminated. The conflict between work and family has brought great pressure on women. They will be guilty, will doubt their own choice, but will be more afraid of the marriage crisis brought by their focusing on work. The contradiction between work and family can't be solved by women themselves. The government and society should pay attention to the plight of women who pursuit their career and coordinate their family life at the same time. By establishing special contribution compensation system for women to ease the role of women in conflict, promoting women to become the master in development and get rid of the subordinate status. For example, compensation for procreation cost and child-rearing cost, compensation for women who can balance work and family, promoting housework in exchange for salary and housework socializing and so on.

\section{At the Level of Women's Policy Implementation}

Since reform and opening-up, with China's decentralization from central to local and from government to society, the situation of Ineffective implementation of women's policy has happened in varying degrees at all levels of government in our country at present. A lot of good rules about promoting gender equality encountered "resistance" and "evaporation" because of Ineffective implementation. For example, the existing laws including "Constitution" and "Labor law" have explicitly stipulated that men and women enjoy equal right to work. But in reality, women with employment rights and skills equal with men are being treated differently for gender differences. At the system, policy and law enforcement level, we should focus on improving the implementation of the women's policy. I think we should do the following work:

1. Improve the operability of women's policies, laws and regulations;

2. Strengthening the training to raise the gender consciousness of women's policy executor;

3. Improve the construction of information communication mechanism for implementing gender policy and increase women's participation in non-governmental organizations;

4. Paying attention to performance evaluation and optimizing government management when monitoring implementing gender policy.

\section{Reference}

[1] Bureau for Gender Equality Gender: A Partnership of Equal [J]. Geneva, 2000, (5).

[2] China Translation \& Publishing Company: Tanjing Chang, Xinchun Ying. English-Chinese Women and Law Vocabulary Interpretation [M]. Beijing, 1995, (100).

[3] Contemporary China Publishing House: Lihui Ying. Social Gender and Public Policy [M]. Beijing, 2002, (269) 